\title{
Relationships among Increasing Age, Sexual Dysfunction, and Sexual Quality of Life in Married Women of Reproductive Age
} Üreme Çağı Evli Kadınlarında Artan Yaş, Cinsel İşlev Bozukluğu ve Cinsel Yaşam
Kalitesi Arasındaki iliş̧ki

(D) Elçin ZOBAR, iD Hatice KAHYAOĞLU SÜT

Trakya University Health Sciences Institute, Department of Nursing, Edirne, Turkey

\section{ABSTRACT}

Objective: This study aimed to examine the relationship among increasing age, sexual dysfunction, and sexual quality of life (SQL) in married women of reproductive age.

Methods: This cross-sectional study was implemented between July 2015 and April 2016. Married women aged 18-49 years $(n=1,004)$ were stratified according to age groups $(18-19, \mathrm{n}=138 ; 20-24, \mathrm{n}=153$; 25-29, $\mathrm{n}=144 ; 30-34, \mathrm{n}=157 ; 35-39, \mathrm{n}=149 ; 40-44, \mathrm{n}=135 ; 45-49$, $\mathrm{n}=128$ ). Data were collected using an information questionnaire, the Arizona Sexual Experiences Scale-Female (ASEX-F) questionnaire, and the Quality of Sexual Life Questionnaire-Female (SQLQ-F) questionnaire.

Results: Sexual dysfunction (SD) was detected in $68 \%$ of the women. The prevalence of SD increased significantly $(\mathrm{p}<0.001)$ from $51.4 \%$ in the $18-19$ age group to $85.2 \%$ in the $45-49$ age group. In the 45-49 age group, the sexual of quality life was at its lowest $(29.7 \%)(p<0.001)$. Among married women of reproductive age with increasing age and in women in the 45-49 age group, the level of SD increased $(\mathrm{p}=0.021)$, whereas the sexual of quality life decreased $(p<0.001)$. Furthermore, in all age groups, as SD increases, the SQL decreases significantly $(\mathrm{p}<0.001)$.

Conclusion: The prevalence of SD among married women of reproductive age is quite high and increases with age. The highest prevalence of SD is observed in women aged 45-49 years. In all age groups, as SD increases, the SQL decreases.

Keywords: Married women, reproductive age, sexual dysfunction, sexual quality of life

\section{ÖZ}

Amaç: Üreme çağı evli kadınlarında artan yaş, cinsel işlev bozukluğu ve cinsel yaşam kalitesi (CYK) arasındaki ilişkiyi incelemek.

Yöntemler: Kesitsel tipte bu çalışma Temmuz 2015 ile Nisan 2016 tarihleri arasında yürütüldü. 18-49 yaşlarındaki $(n=1,004)$ evli kadınlar yaş gruplarına $(18-19, \mathrm{n}=138 ; 20-24, \mathrm{n}=153 ; 25-29$, $\mathrm{n}=144 ; 30-34, \mathrm{n}=157 ; 35-39, \mathrm{n}=149 ; 40-44, \mathrm{n}=135 ; 45-49, \mathrm{n}=128$ kadın) göre sınıflandırıldı. Veriler bir bilgi formu, Arizona Cinsel Yaşantılar Ölçeği-Kadın Formu (ACYÖ-K) ve CYK Ölçeği-Kadın Formu (CYKÖ-K) kullanılarak topland.

Bulgular: Kadınların \%68'inde cinsel işlev bozukluğu (CİB) saptand. CİB prevalansının 18-19 (\%51,4) ile 45-49 $(\% 85,2)$ yaş aralığında anlamlı derecede arttığı $(\mathrm{p}<0,001)$ gözlendi. Kırk beş49 yaş aralığında, CYK en düşük düzeydeydi $(\% 29,7)(\mathrm{p}<0,001)$. Evli kadınlarda yaş arttıkça ve 45-49 yaş grubundaki kadınlarda CİB artmış $(p=0,021)$, CYK azalmıştır $(p<0,001)$. Ayrıca tüm yaş gruplarında CİB arttıkça, CYK önemli ölçüde azalmaktadır $(\mathrm{p}<0,001)$.

Sonuç: Üreme çağındaki evli kadınlar arasında CİB prevalansı oldukça yüksektir ve yaş arttıkça artmaktadır. En yüksek CİB prevalansı 45-49 yaş grubundaki kadınlarda görülür. Tüm yaş gruplarında, CİB arttıkça, kaliteli yaşamın cinsiyeti azalır.

Anahtar Sözcükler: Evli kadın, üreme çağı, cinsel işlev bozukluğu, cinsel yaşam kalitesi

Address for Correspondence: Hatice KAHYAOČLU SÜT, Trakya University Health Sciences Institute, Department of Nursing, Edirne, Turkey

E-mail: haticesut@yahoo.com ORCID ID: orcid.org/0000-0001-8840-6846

Cite this article as: Zobar E, Kahyaoğlu Süt H. Relationships among Increasing Age, Sexual Dysfunction, and Sexual Quality of Life in Married Women of Reproductive Age. Bezmialem Science 2021;9(4):399-406. 


\section{Introduction}

Sexual dysfunction (SD) in women is a multidimensional problem that has a negative influence on holistic well-being (1). It is described as a recurrent or permanent lack of sexual drive and sexual arousal, pain during sexual intercourse, and difficulties or a permanent difficulty in achieving orgasm (2). SD expresses the difficulties that occur during the sexual reaction cycle that prevent the individual from achieving satisfaction during sexual activity (3). SD is a problem that increases with age and affects $30 \%-50 \%$ of women; its prevalence in women of reproductive age is quite high $(4,5)$. Social and cultural restrictions, as well as cultural taboos, make it quite difficult to precisely determine the prevalence of SD among women. Previous studies have reported that the prevalence of $\mathrm{SD}$ in women of reproductive age was $52 \%$ in Iran, 63\% in Nigeria, and 45.6\% in Egypt $(1,6,7)$. In Turkey, studies have observed that the prevalence of SD varied between $45.0 \%$ and $69.8 \%(8-10)$.

Sexual quality of life (SQL) speaks to the existence of a general level of well-being regarding sexuality and sexual satisfaction (11). SD can negatively affect the SQL of married women (12). In married life, which embodies spiritual, emotional, and sexual elements, the happiness of couples is heavily dependent on a healthy relationship and SQL (13). As a negative effect on the SQL of married women, SD can destroy the relationship between partners (14).

Multidimensional, cultural, and ethnic factors that dominate all societies have influenced the prevalence of SD (15). In all societies, the most effective common factor for SD in women is age. Throughout the woman's life, the prevalence of SD increases with age. In Jordan, the prevalence of SD was at its lowest levels among women aged $<18$ years and at its highest levels among women aged $>40$ years, with age seen as the most significant risk factor (16). In married Turkish women, studies have also reported increases in the prevalence of SD with age $(8,17)$. In Iran, the prevalence of SD increases with age; SD affects $26 \%$ of women in the 20-39 age group and 39\% of those aged $>50$ years (18).

Women's sexual life is influenced by psychological, interpersonal, and physiological factors. In married women of reproductive age, aging associated with sexuality led to a decline in interactions between married couples and an increase in sexual problems (12). Thus, for the general health of marital relationships, married women should share any aging-related SD problems with healthcare professionals and subsequently seek treatment. To the best of our knowledge, no studies have examined the relationship among increasing age, SD, and SQL in married women.

Thus, this study aimed to examine the relationship among increasing age, SD, and SQL of married women of reproductive age.

\section{Methods}

This cross-sectional study was implemented between July 2015 and April 2016 among married women residing in the city centers of the Edirne and Kirklareli provinces of Turkey. The study population consisted of 89,372 and 77,330 women residing in Edirne and Kırklareli, respectively, all aged 18-49 years (Turkish Statistical Institute, 2014). The sample size was determined as 980 women based on the effect of 21 possible independent factors on the scores of the SQL scale, with a $\mathrm{R}^{2}$ of 0.03 , alpha of $5 \%$, and power of $80 \%$. However, 1004 women were included in the study considering the probability of missing data. As per data from the Turkish Statistical Institute (2014), 1,004 people were weighted according to their city population. The sample included 537 married women from Edirne City and 467 from Kurklareli City. Using a stratified sampling method $(\mathrm{n}=1,004)$, women were stratified by age groups: $18-19, \mathrm{n}=138$; $20-24, \mathrm{n}=153 ; 25-29, \mathrm{n}=144 ; 30-34, \mathrm{n}=157 ; 35-39, \mathrm{n}=149$; $40-44, n=135 ; 45-49, n=128$. The address of married women in the 18-49 age group was obtained from their neighborhood official, and in the final stage, a simple random sampling method was used. Women who were married, healthy, sexually active, not pregnant, non-menopausal, and willing to participate in the study were included.

Ethical approval for the study was obtained from the Trakya University Scientific Research Ethics Committee. The participants were informed about the study, and they signed the informed consent form accompanying the questionnaire.

Data were collected through a data questionnaire, Arizona Sexual Experiences Scale-Female (ASEX-F) questionnaire, and SQL Questionnaire-Female (SQLQ-F) form. First, volunteer participants were informed about the purpose of the study and how to fill out the data form. Then, they were left alone for approximately $20 \mathrm{~min}$ to complete the data questionnaire. The survey questionnaire, which was prepared by the researchers after an examination of the literature, consisted of 11 questions, of which seven were about the women's attributes and four were about their sexual lives $(8,13,17,19,20)$.

ASEX-F: This tool was developed in 2000 by McGahuey et al. (21) for the assessment of SD in women. The ASEX-F was adapted in 2004 to Turkish by Soykan (22). The scale consists of five items and is evaluated using a six-point Likert scale. The scale has the following five subdimensions: sexual drive, arousal, vaginal lubrication, sexual satisfaction, and orgasm. Each scale item is scored from 1 to 6 points (ranging from 1 indicating hyperfunction to 6 presenting hypofunction). The lowest and highest scores are 5 and 30 points, respectively. A low score demonstrates that $S D$ is not evident, whereas a high score demonstrates the presence of SD. According to Soykan, the cutoff score for the scale to detect sexual symptoms was 11 points (22). The Cronbach's alpha value of the scale was 0.90 according to Soykan (22), and in the current study, it was 0.92.

The SQLQ-F was developed in 2005 by Symonds et al. (23), and the Turkish adaptation was performed by Tuğut and Gölbaşı (24) in 2010. The scale consists of 18 items with a six-point Likert scale and can be applied to all women aged $>18$ years. Women are expected to answer each item by reflecting on their sexual lives over the previous 4 weeks. The score ranges from 18 to 108 
points. A high score received from the scale demonstrates that the SQL level is also high. Its Cronbach's alpha value according to Tuğut and Gölbaşı (24) was 0.83. In the present study, its Cronbach's alpha value was 0.94 , and the cutoff point of the SQLQ-F total score was $>62.2$ by using the receiver operating characteristics (ROC) analysis. The area value under the ROC curve (AUC $=0.890)$ was quite high and significant $(\mathrm{p}<0.001)$. At this cutoff point, very high predictive values (sensitivity, 93.3\%; specificity, 75.4\%; positive predictive value, 93.3\%; negative predictive value, 70.9\%) were obtained (Figure 1). Accordingly, in the present study, those with an SQLQ-F cutoff score $>62$ were assessed to have a good SQL.

\section{Statistical Analysis}

In the data analysis, SPSS 20.0 software package (IBM Corp., Armonk, NY, USA) was used. The normality distribution of quantitative data was tested by the one-sample KolmogorovSmirnov test. For the comparison of the ASEX-F and SQLQ-F scores according to age categories, a one-way analysis of variance test was used. A chi-square test was used to compare categorical data. Spearman correlation analysis was used to analyze the relationship between ASEX-F and SQLQ-F scores. With the ROC analysis, the cutoff value of the SQLQ-F total average score was found, and according to this cutoff value, the sensitivity, specificity, and positive predictive values were calculated. The results are shown as mean \pm standard deviation or number (\%), and $\mathrm{p}<0.05$ was accepted as the limit value of significance.

\section{Results}

The background personal attributes of married women of reproductive age are shown in Table 1 . The distribution of the participants according to the age groups was as follows: $13.7 \%$, 18 -19 age group; $15.3 \%, 20-24$ age group; $14.3 \%, 25-29$ age group; $15.7 \%, 30-34$ age group; $14.8 \%, 35-39$ age group; $13.5 \%$, 40-44 age group; $12.7 \%$, $45-49$ age group. Edirne was

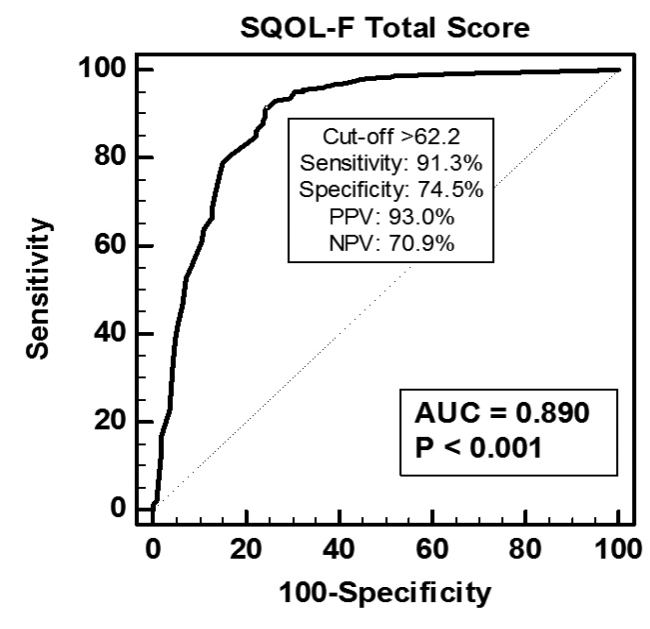

Figure 1. Quality of sexual life questionnaire-female cutoff score calculation according to the receiver operating characteristics analysis home to $53.4 \%$ of the women, and $46.6 \%$ of the women resided in Kirklareli. Moreover, $56.8 \%$ of the participants had attended high school or obtained tertiary-level education. Additionally, $83.4 \%$ of the women were members of nuclear families, $51.6 \%$ were employed, and $63.9 \%$ had income levels equal to

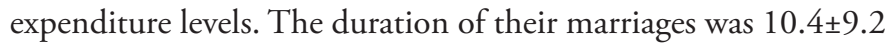
years (Table 1).

In this study, the attributes of the sexual lives of all age groups (18-19, 20-24, 25-29, 30-34, 35-39, 40-44, and 45-49) were compared. Moreover, $78.1 \%(n=1004)$ of the participants were satisfied with their sexual lives; women in the 20-24 age group $(86.9 \%)$ had the highest level of satisfaction, whereas those in the 45-49 age group (50.8\%) had the lowest level of satisfaction. Moreover, $41.8 \%$ of the women who most frequently regarded sexuality as a "natural need" belonged to the 20-24 age group, and $28.9 \%$ who least frequently regarded sexuality as a "natural need" were part of the 45-49 age group. Women who most

Table 1. Personal attributes of married women of reproductive age $(n=1.004)$

\begin{tabular}{|c|c|c|}
\hline & $n$ & $\%$ \\
\hline \multicolumn{3}{|l|}{ Age } \\
\hline $18-19$ & 138 & 13.7 \\
\hline $20-24$ & 153 & 15.3 \\
\hline $25-29$ & 144 & 14.3 \\
\hline $30-34$ & 157 & 15.7 \\
\hline $35-39$ & 149 & 14.8 \\
\hline $40-44$ & 135 & 13.5 \\
\hline $45-49$ & 128 & 12.7 \\
\hline \multicolumn{3}{|l|}{ Place of residence } \\
\hline Edirne/center & 536 & 53.4 \\
\hline Kırklareli/center & 468 & 46.6 \\
\hline \multicolumn{3}{|l|}{ Education level } \\
\hline Primary and lower & 434 & 43.2 \\
\hline High school and higher & 570 & 56.8 \\
\hline \multicolumn{3}{|l|}{ Family structure } \\
\hline Nuclear family & 837 & 83.4 \\
\hline Extended family & 167 & 16.6 \\
\hline \multicolumn{3}{|l|}{ Employment status } \\
\hline Not working & 486 & 48.4 \\
\hline Working & 518 & 51.6 \\
\hline \multicolumn{3}{|l|}{ Income status } \\
\hline $\begin{array}{l}\text { Income level less than expenditure } \\
\text { level }\end{array}$ & 230 & 22.9 \\
\hline $\begin{array}{l}\text { Income level equal to expenditure } \\
\text { level }\end{array}$ & 642 & 63.9 \\
\hline $\begin{array}{l}\text { Income level higher expenditure } \\
\text { level }\end{array}$ & 132 & 13.1 \\
\hline & $\hat{A} \pm S D$ & \\
\hline Marriage year & $10.4 \pm 9.2$ & \\
\hline Mean (Â), SD: Standard deviation & & \\
\hline
\end{tabular}


frequently regarded sexuality as "the most important bond with their partners" belonged to the 25-29 age group (56.3\%), and the women who least frequently regarded sexuality in this way were part of the 45-49 age group (36.7\%). Sexuality was regarded as "unnecessary except for reproductive purposes" most frequently by women in the $45-49$ age group $(18.0 \%)(\mathrm{p}<0.001)$. The frequency of daily sexual intercourse was highest $(24.6 \%)$ in the 18-19 age group, whereas women in the 20-24 age group had sexual intercourse 3-4 times a week (64.1\%), and those in the 40-44 age group had sexual intercourse 1-2 times a week (53.3\%). In addition, $46.1 \%, 16.4 \%$, and $5.5 \%$ of the women in the 45-49 age group had sexual intercourse 1-2 times a week, 1-2 times a month, and 1-2 times every 3 weeks, respectively $(\mathrm{p}<0.001)$. In this study, $96.5 \%$ of the women in the $25-29$ age group most frequently stated that foreplay before sexual intercourse was important, and $75.8 \%$ of the women who least frequently expressed the same sentiments belonged to the 45-49 age group $(\mathrm{p}<0.001)($ Table 2$)$.
In this study, the average ASEX-F score of married women of reproductive age was $13.4 \pm 5.4$. The ASEX-F average score of women in the 45-49 age group (16.6 \pm 5.9$)$ was significantly higher than that of women in the other age groups (18-19, 20$24,25-29,30-34,35-39$, and 40-44) $(\mathrm{p}=0.021)$. According to ASEX-F, SD was found in $68 \%$ of the women. Based on age range, the prevalence of $\mathrm{SD}$ was significantly increased from $51.4 \%$ in the 18-19 age group [(subsequent age groups: 20-24 age group (51.6\%), 25-29 age group (64.6\%), 30-34 age group (71.3\%), and $40-44$ age group $(81.5 \%)]$ to $85.2 \%$ in the $45-49$ age group $(\mathrm{p}<0.001)$. The average SQLQ-F score of the women was $74.2 \pm 21.0$. Following a comparison between age range and the average SQLQ-F score of the women, the average SQLQ-F score of women in the 45-49 age group $(60.9 \pm 23.7)$ was significantly lower than that of the women in the other age groups (18-19, 20-24, 25-29, 30-34, 35-39, and 40-44) ( $\mathrm{p}<0.001)$. According to the average SQLQ-F score, where the cutoff value was $\leq 62$, the SQL of $23.3 \%$ of the women was poor, and with the cutoff value of $>62$, the SQL of $76.7 \%$ of the women was good. In

Table 2. Comparison of attributes of women's sexual lives according to age group $(n=1004)$

\begin{tabular}{|c|c|c|c|c|c|c|c|c|c|}
\hline \multicolumn{10}{|c|}{ Age groups } \\
\hline & $\begin{array}{l}18-49 \\
(n=1004)\end{array}$ & $\begin{array}{l}18-19 \\
(n=138)\end{array}$ & $\begin{array}{l}20-24 \\
(n=153)\end{array}$ & $\begin{array}{l}25-29 \\
(n=144)\end{array}$ & $\begin{array}{l}30-34 \\
(n=157)\end{array}$ & $\begin{array}{l}35-39 \\
(n=149)\end{array}$ & $\begin{array}{l}40-44 \\
(n=135)\end{array}$ & $\begin{array}{l}45-49 \\
(n=128)\end{array}$ & $\mathrm{P}^{*}$ \\
\hline & $\mathrm{n} \%$ & $\mathrm{n} \%$ & $\mathrm{n} \%$ & $\mathrm{n} \%$ & $\mathrm{n} \%$ & n \% & $\mathrm{n} \%$ & $\mathrm{n} \%$ & \\
\hline \multicolumn{10}{|c|}{ Satisfaction from sexuality } \\
\hline Yes & $784(78.1)$ & $111(80.4)$ & $133(86.9)$ & $124(86.1)$ & $126(80.3)$ & $116(77.9)$ & $109(80.7)$ & $65(50.8)$ & \multirow{2}{*}{$<0.001$} \\
\hline No & $220(21.9)$ & $27(19.6)$ & $20(13.1)$ & $20(13.9)$ & 31(19.7) & $33(22.1)$ & $26(19.3)$ & 63 (49.2) & \\
\hline \multicolumn{10}{|l|}{ Viewpoint on sexuality } \\
\hline Natural need & $355(35.4)$ & $42(30.4)$ & $64(41.8)$ & $53(36.8)$ & $61(38.9)$ & $50(33.6)$ & $48(35.6)$ & $37(28.9)$ & \multirow{6}{*}{$<0.001$} \\
\hline $\begin{array}{l}\text { The most important } \\
\text { bond between me and } \\
\text { my partner }\end{array}$ & $486(48.4)$ & $68(49.3)$ & $73(47.7)$ & $81(56.3)$ & $87(55.4)$ & $68(45.6)$ & $63(45.9)$ & $47(36.7)$ & \\
\hline $\begin{array}{l}\text { Unnecessary outside } \\
\text { reproductive purposes }\end{array}$ & $82(8.2)$ & $5(3.6)$ & $8(5.2)$ & $5(3.5)$ & $4(2.5)$ & $20(13.4)$ & $17(12.6)$ & $23(18.0)$ & \\
\hline Shame/sin & $48(4.8)$ & $20(14.5)$ & $5(3.3)$ & $5(3.5)$ & $2(1.3)$ & $4(2.7)$ & $2(1.5)$ & $10(7.8)$ & \\
\hline I detest it & $25(2.5)$ & $3(2.2)$ & $2(1.3)$ & $0(0.0)$ & $2(1.3)$ & $7(4.7)$ & $3(2.2)$ & $8(6.3)$ & \\
\hline $\begin{array}{l}\text { It has no place in my } \\
\text { life }\end{array}$ & $8(0.8)$ & $0(0.0)$ & $1(0.7)$ & $0(0.0)$ & $1(0.6)$ & $0(0.0)$ & $3(2.2)$ & $3(2.3)$ & \\
\hline \multicolumn{10}{|c|}{ Sexual intercourse frequency } \\
\hline Every day & $82(8.2)$ & $34(24.6)$ & $22(14.4)$ & $9(6.3)$ & $6(3.8)$ & $5(3.4)$ & $3(2.2)$ & $3(2.3)$ & \multirow{6}{*}{$<0.001$} \\
\hline 3-4 times a week & $434(43.2)$ & $84(60.9)$ & $98(64.1)$ & $70(48.6)$ & $76(48.4)$ & $57(38.3)$ & $29(21.5)$ & $20(15.6)$ & \\
\hline 1-2 times a week & $336(33.5)$ & 15 (10.9) & $21(13.7)$ & $54(37.5)$ & $55(35.0)$ & $60(40.3)$ & $72(53.3)$ & $59(46.1)$ & \\
\hline $\begin{array}{l}1-2 \text { times every } 2 \\
\text { weeks }\end{array}$ & $72(7.2)$ & $2(1.4)$ & $7(4.6)$ & $5(3.5)$ & $10(6.4)$ & $9(6.0)$ & $21(15.6)$ & $18(14.1)$ & \\
\hline $\begin{array}{l}1-2 \text { times every } 3 \\
\text { weeks }\end{array}$ & $27(2.7)$ & $3(2.2)$ & $2(1.3)$ & $1(0.7)$ & $4(2.5)$ & $8(5.4)$ & $2(1.5)$ & $7(5.5)$ & \\
\hline $1-2$ times a month & $53(5.3)$ & $0(0.0)$ & $3(2.0)$ & $5(3.5)$ & $6(3.8)$ & $10(6.7)$ & $8(5.9)$ & $21(16.4)$ & \\
\hline \multicolumn{10}{|c|}{ Importance of foreplay before sexual intercourse } \\
\hline Yes & $896(89.2)$ & $128(92.8)$ & $143(93.5)$ & $139(96.5)$ & $142(90.4)$ & $133(89.3)$ & $113(83.7)$ & $98(75.8)$ & \multirow{2}{*}{$<0.001$} \\
\hline No & $108(10.8)$ & $10(7.2)$ & $10(6.5)$ & $5(3.5)$ & $15(9.6)$ & $16(10.7)$ & $22(16.3)$ & $30(23.4)$ & \\
\hline
\end{tabular}


the 25-29 age group (6.9\%), the SQL was at its lowest level. In the 45-49 age group (29.7\%), the decline in the SQL was at its highest $(\mathrm{p}<0.001)$ (Table 3).

In this study, a significant negative relationship was detected between the ASEX-F scores for all age groups (18-19, 20-24, 25-29, 30-34, 35-39, 40-44, and 45-49); their average scores for the subdimensions sexual drive, arousal, vaginal lubrication, sexual satisfaction, and orgasm; and their SQLQ-F score average $(\mathrm{p}<0.001)$ (Table 4).

\section{Discussion}

In this study, we found that the prevalence of SD among married women of reproductive age is high; in all age groups, the prevalence of SD increases as age increases, and as the level of SD increases, the SQL decreases.

This study examined the relationships between increasing age, $\mathrm{SD}$, and SQL in married women of reproductive age. Of the women, 68\% reported SD (ASEX-F score $\geq 11$ ). Significantly, an increased prevalence of SD was observed between those in the
18-19 (51.4\%) and 45-49 (85.2\%) age groups. An examination of similar studies carried out in different regions in Turkey showed that SD was reported by Ege et al. (25) in $45.6 \%$ of women, Öksüz and Malhan (26) in 48.3\%, Cayan et al. (8) in 46.9\%, Demir et al. (27) in 28.6\%, Ozturk et al. (9) in 69.8\%, Artune-Ulkumen et al. (28) in 36.8\%, and Yilmaz et al. (10) in $45.0 \%$ of women. The prevalence of SD among women of reproductive age was $52 \%$ in an analysis undertaken in Iran (6). In Nigeria, Fajewonyomi et al. (7) found that $63 \%$ of the women of reproductive age had SD. In Egypt, Gabr et al. (29) found that $30 \%$ of fertile women had SD, and Mustafaa et al. (1) reported 45.6\%. Mishra et al. (30) found that $55.5 \%$ of fertile Indian women had SD. In studies based on age range, Özerdoğan et al. (31) found SD in 53.9\% of Turkish women in the 40-44 age group and $65.8 \%$ in the $45-49$ age group. Oksuz and Malhan. (32) found SD in $41 \%$ of Turkish women in the $18-30$ age group, $53.1 \%$ in the $31-45$ age group, and $67.9 \%$ in the $46-$ 55 age group. Aslan et al. (17) found an age-related increase in the prevalence of SD in Turkish women, with 22\%, 39.7\%, and $50.2 \%$ in the 20-29, 30-39, and 40-49 age groups, respectively. Cayan et al. (8) reported an increase in the prevalence of SD

Table 3. Comparison of SD and SQL prevalence and ASEX-F and SQLQ-F score averages by age groups ( $n=1,004)$

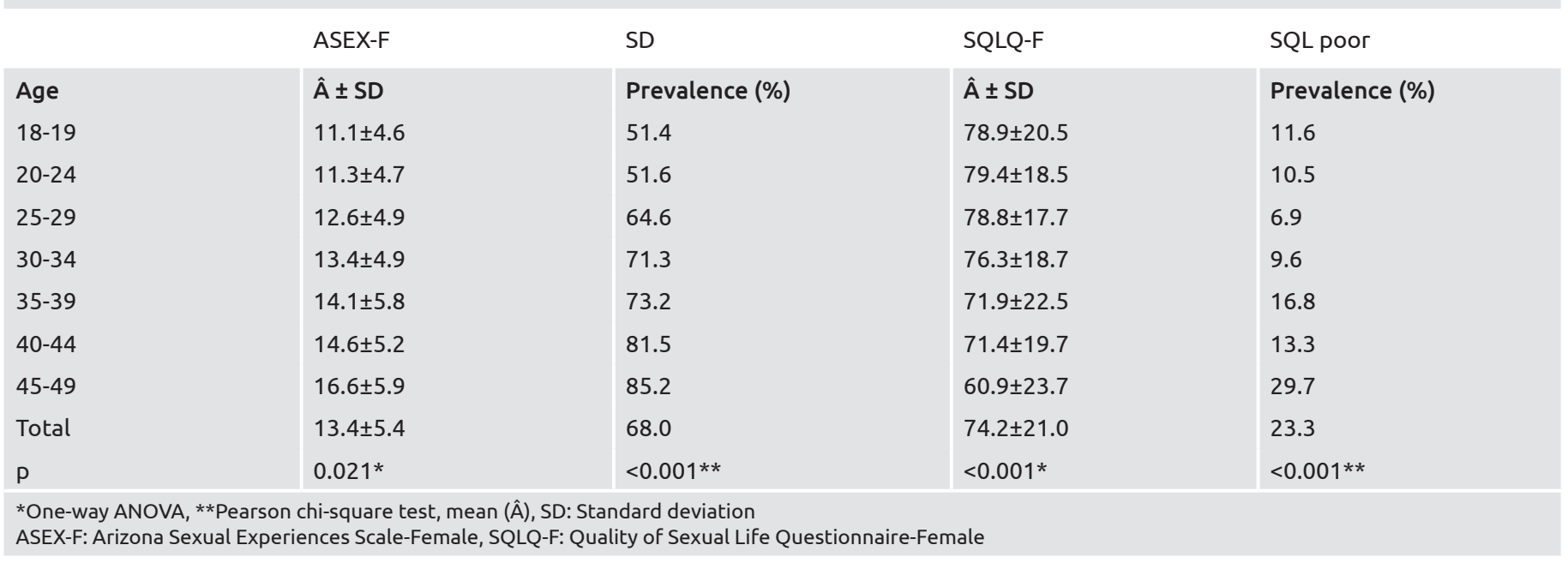

Table 4. Relation between the ASEX-F total and subdimension score averages and SQLQ-F score averages according to age groups

\begin{tabular}{|c|c|c|c|c|c|c|c|c|}
\hline & \multicolumn{2}{|c|}{ Age groups } & ASEX-F total & Sexual drive & Arousal & $\begin{array}{l}\text { Vaginal } \\
\text { lubrication }\end{array}$ & $\begin{array}{l}\text { Sexual } \\
\text { satisfaction }\end{array}$ & Orgasm \\
\hline \multirow{7}{*}{ SQLQ-F total } & $18-19$ & r & $-0.613^{*}$ & $-0.576^{*}$ & $-0.562 *$ & $-0.468 *$ & $-0.524^{*}$ & $-0.601 *$ \\
\hline & $20-24$ & r & $-0.507^{*}$ & $-0.519 *$ & -0.370 * & $-0.334^{*}$ & $-0.447 *$ & $-0.475^{*}$ \\
\hline & $25-29$ & r & -0.460 * & $-0.401^{*}$ & $-0.338 *$ & $-0.362^{*}$ & $-0.408^{*}$ & $-0.355^{*}$ \\
\hline & $30-34$ & r & $-0.539 *$ & $-0.519 *$ & $-0.422^{*}$ & $-0.486^{*}$ & $-0.467^{*}$ & $-0.458^{*}$ \\
\hline & $35-39$ & r & $-0.670 *$ & $-0.600 *$ & $-0.569 *$ & $-0.535^{*}$ & $-0.596^{*}$ & $-0.668 *$ \\
\hline & $40-44$ & r & $-0.628 *$ & $-0.542^{*}$ & $-0.480 *$ & $-0.569 *$ & $-0.452^{*}$ & $-0.603 *$ \\
\hline & $45-49$ & г & $-0.721 *$ & $-0.593^{*}$ & $-595 *$ & $-0.651^{*}$ & $-0.583^{*}$ & $-0.717^{*}$ \\
\hline
\end{tabular}


with age in Turkish women, i.e., $21.7 \%$ in the $18-27$ age group and $92.9 \%$ in the 58-67 age group. In Iran, the prevalence of SD in women was reported to increase with age, affecting $26 \%$ of women in the 20-39 age range and 39\% in those aged $>50$ years (18). In Jordan, Maita et al. (16) found that the prevalence of SD was at its lowest level among those aged $<18$ years and the highest level in women aged $>40$ years. Mishra et al. (30) reported that SD was more common in fertile Indian women aged 26-30 and $>41$ years. The prevalence of SD is quite high in married women of reproductive age, which increases with age. In the present study, $78.1 \%$ of the women stated that they were satisfied with their sexual life, and the possible reason for this high satisfaction rate is that women are unwilling to share their sexual problems because of cultural reasons.

In the present study, $76.7 \%$ and $23.3 \%$ of married women of reproductive age had high and poor SQL, respectively. Tuncer et al. (33), Taskin Yilmaz et al. (34), Dogan et al. (20), and Yaralı and Hacialioglu. (35) reported that married Turkish women had good SQL (21). Strizzi et al. (36) found that healthy women had good SQL. Moreover, SQL was good in most married and healthy women of reproductive age. In the present study, the SQL varied according to the age group of married women of reproductive age. Those (29.7\%) in the 45-49 age group had poor SQL. Dogan et al. (20) reported a positive relationship between happiness, life satisfaction, and SQL in married Turkish women. They noted that SQL is an indicator of the level of satisfaction that an individual receives from sex (21). In the present study, the 20-24 age group (86.9\%) had the highest satisfaction level from sex, and the 45-49 age group (50.8\%) presented the lowest level of satisfaction. The incidence of hypoactive sexual desire disorder may increase with advancing age; therefore, women can experience sexual interest and arousal disorder. In women aged 45-49 years, the level of satisfaction derived from sex decreases, and their views related to sexuality became increasingly negative.

In the present study, the level of SD increased, whereas SQL decreased in married women of reproductive age and women aged 45-49 years. Moreover, in all age groups, as SD increases, the SQL decreases, and a significant relationship was found between the two. In their analysis of married women, Sahin et al. found that SD increased with age and women aged $\geq 45$ years had a higher level of SD. In addition, SD is more common in those who had been married between 2 and 9 years (37). Moreover, SD increases with the age of the married Egyptian women and with the age of her partner (1). Again, in married Egyptian women, age was found as a risk factor for SD (38). In Chinese women, a significant relationship was found between age and SD, with SD becoming more frequent with age (39); a decrease in vaginal lubrication and an increase in the frequency of pain during intercourse were also reported (40). Lin et al. (41) found a significant relationship between age and SD, and as age increases, the frequency of SD increases, which negatively affects SQL. Likewise, Shin et al. (42) reported a significant relationship between age and SD, and as age increases, there is a concomitant decrease in vaginal lubrication and an increase in the frequency of pain during sexual intercourse, with SD levels increasing overall and negatively affecting SQL. Sathyanarayana Rao et al. (43) reported an increase in SD in women aged 31-50 years. Fajewonyomi et al. (7) reported that SD most frequently occurred in Nigerian women aged 26-30 years. Zhang et al. (44) found that the increase in sexual symptoms was most common in married women in the 41-49 age group. Regarding studies among Turkish women aged $>49$ years, Özerdoğan et al. (31) reported that SD was present in $78 \%$ of women aged $\geq 50$ years and that there was an increase in the SD/age ratio (32). Kömürcü and Işbilen (45) noted that SD is more widespread in women aged $\geq 50$ years than in other age groups. According to Mishra et al. (30), SD was more common in fertile Indian women aged 26-30 years and aged >41 years, and those with sexual desire dysfunction had severe SD (31). Oniz et al. (46) found that women aged 19-51 years reported an increased number of symptoms if they had been married for $>11$ years. According to Haghi et al. (12), marital closeness in married Iranian women aged 20-35 years was closely related to SQL and SD. In line with the literature, SD also increases with an increase in age, and as sexual symptoms increase, SQL decreases. Compared with other age groups, women in the 45-49 age group exhibited an increase in hormonal (in women, androgen hormone level decreases with increasing age, which results in decreased sexual interest and arousal) and physical changes due to menopause, decline in sexual closeness between partners, and inability to share sexual problems because of cultural reasons, which resulted in a more severe SD and a poorer SQL.

\section{Study Limitation}

The strengths of this study were related to its inclusion of healthy, sexually active, non-pregnant, non-menopausal, and married women aged 18-49 years. Women were selected by using a stratified sampling method. Women were visited in their homes by the same researcher. However, the study has limited generalizability because it was only conducted in two cities in Turkey.

\section{Conclusion}

The prevalence of SD among married women of reproductive age is quite high and increases with age. SQL was observed to be poorest in women aged 45-49 years. In all age groups, as $\mathrm{SD}$ increases, SQL decreases. In women of reproductive age, diagnosing and treating sexual problems through family health policies is important to maintain the holistic well-being of women and mitigate the likelihood of marital conflicts.

\section{Ethics}

Ethics Committee Approval: Ethical approval for the study was obtained from the Trakya University Scientific Research Ethics Committee.

Informed Consent: The participants were informed about the study, and they signed the informed consent form accompanying the questionnaire. 
Peer-review: Externally peer reviewed.

\section{Authorship Contributions}

Concept: E.Z., H.K.S., Design: E.Z., H.K.S., Data Collection or Processing: E.Z., H.K.S., Analysis or Interpretation: E.Z., H.K.S., Literature Search: E.Z., H.K.S., Writing: E.Z., H.K.S.

Conflict of Interest: No conflict of interest was declared by the authors.

Financial Disclosure: The authors declared that this study received no financial support.

\section{References}

1. Mustafaa AI, El EsawyaFM, Fawzyb I. Female sexual dysfunction among married women from the Nile Delta of Egypt. Int J SexHealth 2019;31:131-141.

2. Bassoon R, Berman J, Burnett A, Derogatis L, Ferguson D, Fourcroy $J$. Report of the international consensus development conference on female sexual dysfunction: definitions and classifications. J Urol 2000;163:888-93.

3. Chen CH, Lin YC, Chiu LH, Chu YH, Ruan FF, Liu WM, et al. Female sexual dysfunction: definition, classification, and debates. Taiwan J Obstet Gynecol 2013;52:3-7.

4. Berman JR, Adhikari SP, Goldstein I. Anatomy and physiology of female sexual function and dysfunction: classification, evaluation and treatment options. Eur Urol 2000;38:20-9.

5. Basson R, Althof S, Davis S, Fugl-Meyer K, Goldstein I, Leiblum S, et al. Summary of the recommendations on sexual dysfunctions in women. J Sex Med 2004;1:24-34.

6. Ghiasi A, Keramat A. Prevalence of sexual dysfunction among reproductive-age women in Iran: A systematic reviewand metaanalysis. J Midwifery Reprod Health 2018;6:1390-8.

7. Fajewonyomi BA, Orji EO, Adeyemo AO. Sexual dysfunction among female patients of reproductive age in a hospital setting in Nigeria. J Health Popul Nutr 2007;25:101-6.

8. Cayan S, Akbay E, Bozlu M, Canpolat B, Acar D, Ulusoy E. The prevalence of female sexual dysfunction and potential risk factors that may impair sexual function in Turkish women. Urol Int 2004;72:527.

9. Ozturk S, Sut HK, Kucuk L. Examination of sexual functions and depressive symptoms among infertile and fertile women. Pak J Med Sci 2019;35:1355-60.

10. Yilmaz BA, Sonmez Y, Sezik M. Prevalence and risk factors for sexual dysfunction in reproductive-aged married women: A cross-sectional epidemiological study. J Obstet Gynaecol Res 2020;46:507-16.

11. Gülsün M, Ak M, Bozkurt A. Marriage and Sexuality From a Psychiatric Point of View. Current Approaches in Psychiatry 2009; 1:68-79.

12. Haghi F, Allahverdipour H, Nadrian H, Sarbakhsh P, Hashemiparast M, Mirghafourvand M. Sexualproblems, maritalintimacyandquality of sex life amongmarriedwomen: A studyfrom an Islamiccountry. SexRelationTher 2018;33(3):339-352.
13. Gölbaşı Z, Tuğut N, Şentürk EA, Eroğlu K. Prevalence and some related factor of sexual dysfunction among married women admitted to gynecologicout patient clinic. Cumhuriyet Med J 2014;36:1-10.

14. Morley JE, Kaiser FE. Female sexuality. Med Clin North Am 2003;87:1077-90.

15. Sungur MZ, Bez Y. Cultural factors in the treatment of sexual dysfunction in Muslim clients. Curr Sex Health Rep 2016;8:57-63.

16. Maaita ME, Khreisat BM, Tasso OA, Otom NN, Aljaafreh BM, Abuassaf GM. Prevalence and associated risk factors of female sexual dysfunction among Jordanian women. J Family Med Prim Care 2018;7:1488-92.

17. Aslan E, Beji NK, Gungor I, Kadioglu A, Dikencik BK. Prevalence and risk factors for low sexual function in women: a study of 1,009 women in an outpatient clinic of a university hospital in Istanbul. J Sex Med 2008;5:2044-52.

18. Safarinejad MR. Female sexual dysfunction in a population-based study in Iran: prevalence and associated risk factors. Int J Impot Res 2006;18:382-95.

19. Yilmaz E, Esra Zeytinci I, Sari S, Fatih Karababa I, Savaş Cilli A, Kucur R. Konya Il Merkezi'nde Yaşayan Evli Nüfusta Cinsel Sorunlarin Araştirilmasi [Investigation of sexual problems in married people living in the center of Konya]. Turk Psikiyatri Derg 2010;21:126-34.

20. Dogan T, Tugut N, Golbasi Z. The relationship between sexual quality of life, happiness, and satisfaction with life in married Turkish women. Sex Disabil 2013;31:239-47.

21. McGahuey CA, Gelenberg AJ, Laukes CA, Moreno FA, Delgado PL, McKnight KM, et al. The Arizona Sexual Experience Scale (ASEX): reliability and validity. J Sex Marital Ther 2000;26:25-40.

22. Soykan A. The reliability and validity of Arizona sexual experiences scale in Turkish ESRD patients undergoing hemodialysis. Int J Impot Res 2004;16:531-4.

23. Symonds T, Boolell M, Quirk F. Development of a questionnaire on sexual quality of life in women. J Sex Marital Ther 2005;31:385-97.

24. Tuğut N, Gölbaşı Z. A validity and reliability study of Turkish version of the Sexual Quality of Life Questionnaire-Female. Cumhuriyet Med J 2010;32:172-80.

25. Ege E, Akın B, Arslan SY, Bilgili N. Sağlıklı kadınlarda cinsel fonksiyon bozukluğu sıklığı ve risk faktörleri. TÜBAV J Sci 2010;3:137-44.

26. Öksüz E, Malhan S. Reliability and validity of the Female Sexual Function Index in Turkishpopulation. Sendrom 2005;17:54-60.

27. Demir Ö, Parlakay N, Gök G, Esen AA. Sexual dysfunction in a female hospital staff. Turk J Urol 2007;33:156-60.

28. Artune-Ulkumen B, Erkan MM, Pala HG, Bulbul Baytur Y. Sexual dysfunction in Turkish women with dyspareunia and its impact on the quality of life. Clin Exp Obstet Gynecol 2014;41:567-71.

29. Gabr AA, Omran EF, Abdallah AA, Kotb MM, Farid EZ, Dieb AS, et al. Prevalence of sexual dysfunction in infertile versus fertile couples. Eur J Obstet Gynecol Reprod Biol 2017;217:38-43.

30. Mishra VV, Nanda S, Vyas B, Aggarwal R, Choudhary S, Saini SR. Prevalence of female sexual dysfunction among Indian fertile females. J Midlife Health 2016;7:154-8. 
31. Özerdoğan N, Sayıner FD, Köşgeroğlu N, Ünsal A. The Prevalence of Sexual Dysfunction and Depression and Other Factors Associated in Women 40 to 65 YearsOld. Maltepe University J Nurs Sci Art 2009;2:46-59.

32. Oksuz E, Malhan S. Prevalence and risk factors for female sexual dysfunction in Turkish women. J Urol 2006;175:654-8.

33. Tuncer SK, Aydin E, Kasimoğlu N, Ağdemir B, Başkan SA. Investigation of the effects of marital adjustment on sexual life quality of married women. Asian J Pharm Nurs Med Sci 2018;6:31-44.

34. Taskin Yilmaz F, Karakoc Kumsar A, Demirel G. The effect of body image on sexual quality of life in obese married women. Health Care Women Int 2019;40(4):479-92.

35. Yaralı S, Hacıalioğlu N. Evli kadınlarda cinsel fonksiyon bozukluğu ve cinsel yaşam kalitesinin incelenmesi. Int Refereed J Nurs Res 2016;6:108-27.

36. Strizzi J, Landa LO, Pappadis M, Olivera SL, Tangarife ERV, Agis IF, et al. Sexual functioning, desire, and satisfaction in women with TBI and healthy controls. Behavioural Neurology 2015;2015 247479:7.

37. İrer B, Çelikhisar A, Çelikhisar H, Bozkurt O, Demir Ö. Evaluation of Sexual Dysfunction, Lower Urinary Tract Symptoms and Quality of Life in Men With Obstructive Sleep Apnea Syndrome and the Efficacy of Continuous Positive Airway Pressure Therapy. Urology 2018;121:86-92.

38. Arafa AE, Elbahrawe RS, Shawky SM, Mostafa AM, Ahmed SS, El-Houfey AA, et al. Risk factors associated with female sexual dysfunction among married women in Upper Egypt; a cross sectional study. Int J Community Med Public Health 2018;5:449-53.
39. Lou WJ, Chen B, Zhu L, Han SM, Xu T, Lang JH, et al. Prevalence and Factors Associated with Female Sexual Dysfunction in Beijing, China. Chin Med J (Engl) 2017;130:1389-94.

40. Du J, Ruan X, Gu M, Bitzer J, Mueck AO. Prevalence of and risk factors for sexual dysfunction in young Chinese women according to the Female Sexual Function Index: an internet-based survey. Eur J Contracept Reprod Health Care 2016;21:259-63.

41. Lin MC, Lu MC, Livneh H, Lai NS, Guo HR, Tsai TY. Factors associated with sexual dysfunction in Taiwanese females with rheumatoid arthritis. BMC Women's Health 2017;17:2-7.

42. Shin H, Min B, Park J, Son H. A 10-year interval study to compare the prevalence and risk factors of female sexual dysfunction in Korea: the Korean internet sexuality survey (KISS) 2014. Int J Impot Res 2017;29:49-53.

43. Sathyanarayana Rao TS, Darshan MS, Tandon A. An epidemiological study of sexual disorders in south Indian rural population. Indian J Psychiatry 2015;57:150-7.

44. Zhang H, Fan S, Yip P. Sexual dysfunction among reproductive-aged Chinese married women in Hong Kong: Prevalence, risk factors, and associated consequences. J Sex Med 2015;12:738-45.

45. Kömürcü N, İşbilen A. Adaptation of women to sexual life during the postmenopausal period. Turk J Urol 2011;37:326-30.

46. Oniz A, Keskinoglu P, Bezircioglu I. The prevalence and causes of sexual problems among premenopausal Turkish women. J Sex Med 2007;4:1575-81. 